\title{
Optimization of protein extraction and ELISA immunodetection from protein-based paint models with mesoporous silica nanoparticles and MCM41
}

\author{
Aditya Sandeep Goyal ${ }^{1,2, a}{ }_{\mathbb{D}}$, Cátia Salvador $^{1}{ }_{\mathbb{D}}$, Carole $_{\text {Mathe }^{2}}$, \\ António Candeias $^{1,3}\left(\mathbb{D}\right.$, Ana Teresa Caldeira ${ }^{1,3}$ (D)
}

${ }^{1}$ HERCULES Laboratory and CityUMacau Chair on Sustainable Heritage, Institute for Advanced Studies and Research, Évora University, Largo Marquês de Marialva 8, 7000-809 Évora, Portugal

2 CNRS, Restoration Engineering of Natural and Cultural Heritage, Faculty of Sciences, IMBE UMR 7263/IRD237, Avignon University, IRD/Aix-Marseille University, Campus Jean-Henri Fabre, 301 rue Baruch de Spinoza, BP 21239, 84916 Avignon Cedex 9, France

3 Chemistry Department, School of Sciences and Technology, Évora University, Rua Romão Ramalho 59, 7000-671 Évora, Portugal

Received: 9 December 2020 / Accepted: 31 May 2021

(C) The Author(s) 2021

\begin{abstract}
Protein-based biological materials such as albumin, casein and collagen are found in various cultural heritage $(\mathrm{CH})$ artefacts. This study focuses on the study of protein binders from easel paintings media. Proteins have complex structures which are difficult to identify with non-invasive spectroscopic methods (FT-IR, Raman, UV). Immunoassays such as ELISA determine the protein's source of origin which is necessary for art objects. To increase the detection and identification of proteins by immunoassays, the efficiency of micro-extraction of proteins from heritage materials is a crucial step. Extractions mediated by cycles of orbital agitation and ultrasonic radiation give the possibility to extract proteins from easel painting sample. In this work, protein-based paint models coupled with silica nanoparticles were used for micro-extraction. Nanoparticles possess high surface-to-volume ratios that can attach bioactive molecules such as proteins and increase the total protein recovered from microsamples. Protein extracts were quantified with Bradford Assay in the presence of Coomassie blue. The protein recovery results were statistically computed, and the SPSS analysis shows significant $(p<0.05)$ increase in protein recovery, above 1.3 times for $\mathrm{NPSiO}_{2}$ and above 1.6 times for MCM-41. The statistical data shows evidence that silica nanoparticles intensify the total protein recovered from paint microsamples. Finally, ELISA was realized on the protein extracts to verify and compare the immunodetection of protein from the paint models with and without the use of silica nanoparticles.
\end{abstract}

\footnotetext{
a e-mail: adigo91@gmail.com (corresponding author)
} 


\section{Introduction}

\subsection{Importance of proteins in easel paintings}

In medieval paintings, proteinaceous binders play a significant role in understanding the state of art and helping the process of conservation and restoration [1]. In most paintings, these binders (albumin from chicken eggs, collagen from animal glues and bones, casein from bovine milk) constitute about $20-30 \%$ of the overall paint matter [2-5]. Since the protein constitution is a fraction of the paint media, it requires a multi-analytical approach to determine their origin and properties. In paint media, several sources of protein are present which makes analysis tedious. Analytical techniques such as liquid chromatography coupled to mass spectrometry (LC-MS) give a great deal of information, but require large data extrapolation to identify the protein binder within paint samples [6]. FT-IR does provide some useful information. Most of the data obtained by these methods are targeted towards the identification of pigments, support and varnish or previous restorations, but little information is available about the binders; and if present, interpreting the source of protein origin is not easy [7]. Therefore, in recent times, immunodetection has been employed for characterization of protein binders [4-9]. Immunoassays such as ELISA with specific antibodies work with high accuracy in identifying the biological origin of proteins $[5,6,9]$. ELISA can be used with specific antibodies but involve a step of microsample preparation to be applied with success in heritage context [1,5-7]. For research purposes and optimization, it is important to develop paint models which can act as a representative of original paint samples [1,5]. Paint models are developed with commercially available proteins along with certain pigments that have been found is medieval paintings. Certain ancient recipes can also be useful in determining the types of materials applied to original paintings in the past. For the support on which the paint model is developed, a glass or a canvas slab is appropriate.

\subsection{Role of nanoparticles in protein extraction of paint model microsamples}

Many paint samples are not enough quantitatively for protein extraction. Hence, it is necessary to enhance the protein concentration present in such minute paint samples. With this in mind, in recent times, nanomaterials have made the headlines constantly for having very large surface-to-volume ratios, and have been used in various applications and disciplines ranging from the medical and pharmaceutical industry [10]. The most significant difference between the bulk material particles and nanoparticles is the extremely large surface areas obtained with nanoparticles. This is mostly due to the confinement of electrons within the small size which helps to reproduce quantum effects [11-13]. In previous studies, nanoparticles have been used for several technological applications, but very few for the purpose of cultural heritage [12]. Furthermore, nanoparticles can be easily dispersed and are suitable for impregnation in aqueous suspension into the macrostructure of wood or other materials.

For the purpose of protein applications, mesoporous $(2-50 \mathrm{~nm})$ silica has some excellent properties with high surface adsorption capacities for a large number of bioactive substances [14-17]. Moreover, ordered mesoporous structures have proved to be effective support carriers because of excellent adsorption properties, a high specific surface area and porosity, tunable pore size with narrow distribution, biocompatibility, easy functionalization [18-22]. These advantages are contributed due to their high stability and possibility to modulate the pore size and modify the surface properties by connecting various functional organic groups to the support [23-27]. In particular, MCM-41 and silica monodisperse nanoparticles were exploited for the purpose of our investigation. 
The aim of this study is to exploit silica nanoparticles in the micro-extraction process of proteins from paint model samples and realize the immunodetection of these proteins with ELISA. To further expand, the interaction of proteins with the nanoparticles could increase output yield of protein recovery.

\section{Materials and methods}

\subsection{Materials}

The following reagents were used for sample preparation and ELISA experiments:

Phosphate-buffered saline solution (PBS, $137 \mathrm{mM} \mathrm{NaCl}, 10 \mathrm{mM}$ phosphate $(10,1 \mathrm{mM}$ $\mathrm{Na}_{2} \mathrm{HPO}_{4}, 1,8 \mathrm{mM} \mathrm{KH}{ }_{2} \mathrm{PO}_{4}$ ), 2,7 mM KCl, pH 7,4) was used to dilute antigens and for washing step after the antigen incubation. PBS with Tween-20 (Sigma®), 0.05\% solution (PBS-T), was used for the washing step after the incubation with primary and secondary antibodies.

Bovine serum albumin 1\% (BSA, Acros Organics ${ }^{\mathrm{TM}}$ ) in PBS was used as a blocking solution, and solutions of BSA $0.1 \%$ in PBS and BSA $0.1 \%$ in PBS-T were used to dilute the primary and secondary antibodies, respectively.

Commercial standards of ovalbumin (albumin from chicken egg white, A5378, SigmaAldrich), commercial collagen from rabbit skin (Type I, Sigma-Aldrich), collagen from bovine Achilles tendon (C9879, Sigma-Aldrich) and casein (C3400, Sigma-Aldrich) were used as specific controls for the primary antibodies.

Coomassie blue dye G-250 (Acros Organics ${ }^{\mathrm{TM}}$ ) $[0.6 \%(\mathrm{~m} / \mathrm{v})$ in Hydrochloric acid $0.6 \mathrm{M}$ $(\mathrm{HCl})]$ was used for protein quantification.

The primary antibodies of Monoclonal Anti-chicken Egg Albumin (Ovalbumin) antibody produced in mouse (Reference A6075, Sigma-Aldrich), Monoclonal Anti-Collagen antibody Type I produced in mouse (Reference C2456, Sigma-Aldrich), Polyclonal Anti-Casein Kinase II antibody produced in rabbit (Reference SAB4500514, Sigma-Aldrich) were used after the addition of the antigens.

The secondary antibodies of Monoclonal Anti-mouse IgG (whole molecule)-Alkaline Phosphatase antibody produced in rabbit (Reference A2418, Sigma-Aldrich), Polyclonal Anti-Rabbit IgG (whole molecule)-Alkaline Phosphatase antibody produced in goat (Reference A3687, Sigma-Aldrich) were used to link with the first antibodies.

Glycine buffer solution $\left(0,1 \mathrm{M}, \mathrm{pH} 10,4\right.$, with $1 \mathrm{mM} \mathrm{MgCl}_{2}$ and $\left.1 \mathrm{mM} \mathrm{ZnCl}_{2}\right)$ was used to dilute the substrate p-NPP (1 mg mL-1) and for washing step immediately before the substrate addition.

4-Nitrophenyl phosphate disodium salt hexahydrate (p-nPP, Sigma-Aldrich) was the substrate that produces an optical signal for detection after the antigen-antibody interactions.

The following reagents were used for the synthesis of silica nanoparticles:

Tetraethyl orthosilicate (TEOS) from Sigma-Aldrich, cetyltrimethylammonium bromide (CTAB) from Sigma-Aldrich, ammonium hydroxide $\left(\mathrm{NH}_{4} \mathrm{OH}\right)$ from VWR Chemicals, ethanol $(100 \%)$ from VWR Chemicals and n-hexane from Sigma-Aldrich.

All reagents were used and diluted in de-ionized Millipore water. 


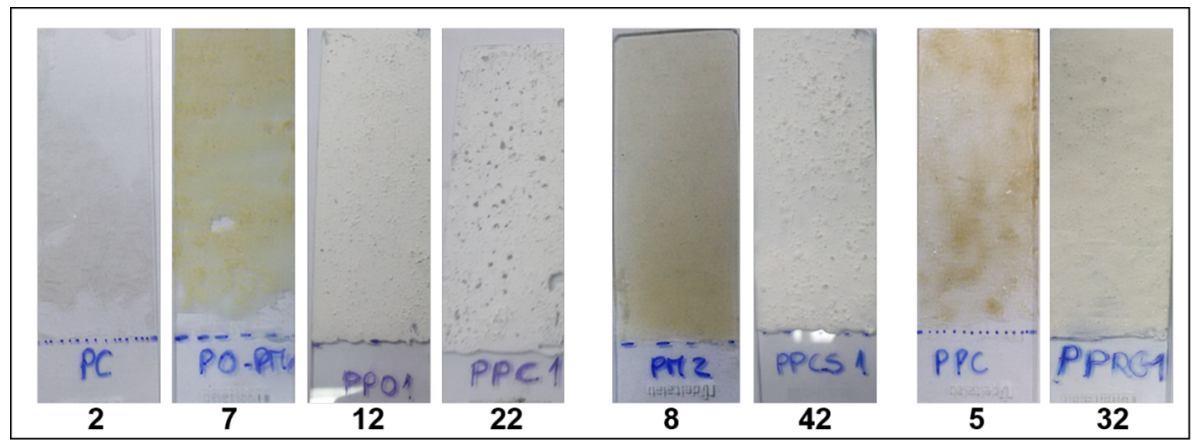

Fig. 1 Paint models of ovalbumin $(2,7,12,22)$; casein $(8,42)$ and collagen $(5,32)$

\subsection{Apparatus}

The following apparatus was used to perform ELISA and related experiments:

96-well Microtiter plates (maximum volume $500 \mu \mathrm{l}$ ) from Nunc ${ }^{\mathrm{TM}}$, 96-well Microtiter plates (maximum volume $150 \mu \mathrm{l}$ ) were used for performing the ELISA and Bradford experiments.

Micropipettes (100-1000 $\mu 1,10-100 \mu 1,0.5-10 \mu 1)$, Microchannel (20-200 $\mu 1)$, Standard Microtips $(10 \mu \mathrm{l}, 200 \mu \mathrm{l}, 1000 \mu \mathrm{l})$, Eppendorf tubes $(1,5 \mathrm{~mL}), 90-\mathrm{mm}$ disc plates, falcon tubes $(50 \mathrm{~mL}, 15 \mathrm{~mL}$ ), Magnetic stirrer, Microplate reader (Thermo Scientific, Model Multiskan Go) and incubator (Memmert, Model IN110), Nalgene Bottles (Thermo Scientific 250 mL PPCO), High-speed Centrifuge (GYROZEN 2236R), Orbital Agitator (IKA KS 4000 I control) were the analytical tools used to perform ELISA in the microtiter plates.

Microplate reader (Thermo Scientific, Model Multiskan Go) was used to read the ELISA plates after the experiment was completed.

An incubator (Memmert, Model IN110) was used for accelerating the ELISA experimental procedure (at $37^{\circ} \mathrm{C}$ ).

The nanoparticles were characterized by TESCAN MIRA-3 FEG-SEM in a vacuum chamber. The XRD images were produced by D8 advance Bruker and the Nitrogen porosimetry was done by Micromeritics Tristar II Plus.

\subsection{Methods}

\subsubsection{Paint models}

In real paintings, it is generally impossible to procure samples large enough for the purpose of research. Therefore, paint models represent and serve as a replacement for real paint samples. In cultural heritage artefacts such as easel paintings, it is important to reproduce these paint models with recipes depicted from the period in which the painting comes from. The paint models usually consist of a protein binder and a pigment and sometimes it can have multiple layers. Only a pigment of lead white was used in these experiments in order to have consistency in protein extraction. Samples were selected for the proteins of ovalbumin, casein and collagen from previously prepared paint models. These paint models are as given in Fig. 1. 
Table 1 Paint models of ovalbumin $(2,7,12,22)$; casein $(8,42)$ and collagen $(5,32)$

\begin{tabular}{ll}
\hline Paint model number & Description \\
\hline 2 & Egg albumin \\
7 & Egg albumin + yolk \\
12 & Whole egg + lead white \\
22 & Egg albumin + lead white \\
8 & Egg albumin + egg yolk + casein \\
42 & Casein from cow's milk + lead white \\
5 & Rabbit skin \\
32 & Rabbit glue + lead white \\
\hline
\end{tabular}

Each of the paint models has a different combination of protein binders and pigments and the motivation was to assess the protein extraction protocol with different paint models in the presence of nanoparticles.

The Table 1 provides the details of each of the paint models with their pigment and binder composition used for the experiments.

\subsubsection{Synthesis of silica nanoparticles}

MCM-41 was synthesized following the emulsion-condensation route reported by Cao et al. [28]. This process uses oil in water emulsion consisting of water, $n$-hexane and the cationic surfactant CTAB. The Stöber process is used in the preparation of monodisperse silica particles in which the simultaneous hydrolysis and condensation of alkyl silicates with ammonia as a catalyst [29]. The synthesis of the silica nanoparticles were done in accordance with the "Stöber Method" for sol-gel formation. There were two different types of nanoparticles synthesized: (1) Monodisperse silica nanoparticles (2) MCM-41 mesoporous silica nanoparticles.

The monodisperse silica nanoparticles $\left(\mathrm{NPSiO}_{2}\right)$ were prepared in accordance with by the following method [30]:

- The molar ratios of TEOS, ethanol and ammonium water were computed to prepare highly concentrated silica nanoparticles. For this synthesis, the molar ratio of TEOS/Ethanol/ $\mathrm{H}_{2} \mathrm{O}$ $\left(\mathrm{NH}_{3} 25 \%\right.$ by weight) was $1: 126: 9$.

- TEOS (Tetraethyloxysilane) was used as the starting material. $2.6 \mathrm{~mL}$ of TEOS was added to a Nalgene bottle. TEOS was dissolved in ethanol $(72,56 \mathrm{~mL})$.

- Separately ammonia water $(4,05 \mathrm{~mL})$ and ethanol were mixed and added to the solution of TEOS, and this entire sol mixture was stirred for $24 \mathrm{~h}$ at room temperature.

- Next, the sol was centrifuged and washed with ethanol three times to remove and unreacted TEOS. The resulting particles was dried in an incubator chamber for about $2 \mathrm{~h}$.

The experimental procedure for the synthesis of MCM-41 is as follows.

In a Nalgene bottle, $70 \mathrm{~mL}$ of distilled water, $0.80 \mathrm{~mL}$ of ammonium hydroxide, $15 \mathrm{~mL}$ of $\mathrm{n}$-hexane, $5 \mathrm{~mL}$ of ethanol and $0.5 \mathrm{~g}$ of CTAB are inserted in succession at room temperature. $2.6 \mathrm{~mL}$ of TEOS were added to the mixture. The molar ratios between the components are reported in Table 2.

Furthermore, the MCM- 41 was calcined in a vacuum chamber at $550^{\circ} \mathrm{C}$ for $6 \mathrm{~h}$. The calcination removes the surfactant $\mathrm{CTAB}$ which provides the morphological permanent structure and pores within MCM-41. It is these empty pores that can then adsorb proteins on the 
Table 2 Molar ratios of different compounds for the synthesis of Silica Mesoporous MCM-41

\begin{tabular}{lllllll}
\hline TEOS & Ethanol & n-Hexane & Water & CTAB & $\begin{array}{l}\text { Ammonium } \\
\text { hydroxide }\end{array}$ & $\mathrm{HCl}$ \\
\hline 1 & 8.7 & 13.9 & 311 & 0.11 & 1.8 & 0.22 \\
\hline
\end{tabular}

surface of the individual nanoparticles within MCM41. The monodisperse silica nanoparticles $\mathrm{NPSiO}_{2}$ was synthesized without any templating agents and therefore was kept in its uncalcined state.

The silica nanoparticles obtained from the modified Stöber method were characterized with SEM to understand the morphological characteristics of the nanoparticles. X-Ray diffraction is performed to confirm the formation of silica nanoparticles with standard XRD images [31]. Finally, nitrogen porosimetry was done on the mesoporous silica nanoparticles to identify their BET surface area, pore volume and Isotherms.

\subsubsection{Micro-extraction of the paint models}

The standard micro-extraction protocol for extracting proteins from the paint models was developed at University of Évora (Patent no. 109572). In this procedure, a paint sample of about 2-3 mg is added to an Eppendorf tube with around $300 \mu \mathrm{l}$ of PBS. This mixture then goes through a series of ultrasonic bath radiation and agitation alternatively three times of $1 \mathrm{~h}$ each for two days with an overnight agitation at room temperature between day 1 and day2. Through various trials, it was postulated that the best way to have consistent results is to add $150 \mu \mathrm{l}$ per mg of sample. Therefore, throughout the experiments, depending on the weight in $\mathrm{mg}$, an equal amount of PBS was added. After this process, the liquid supernatant containing the proteins is extracted carefully and transferred to a different Eppendorf which serves as samples to perform the ELISA experiments.

Microsamples were extracted and dispersed into a PBS solution from each paint model, and the protein was extracted by three consecutive cycles of orbital agitation (at $27{ }^{\circ} \mathrm{C}$ ) and ultrasonication (at $37^{\circ} \mathrm{C}$ ) of $1 \mathrm{~h}$ each. Finally, the extracted protein were quantified by Bradford Assay in the presence of Coomassie Blue G-250. The protein supernatant obtained from the paint models are quantified using the Bradford Assay. The standard curve of BSA standard solutions and the equation was computed as $y=0.0095 x+0.0025$ with an Pearson $R^{2}$ value of 0.9953 , where $y$ is the normalized absorbance of the protein as obtained on the microreader and $\mathrm{x}$ is the protein present in the supernatant in $\mu \mathrm{g} / \mathrm{ml}$.

\subsubsection{Protein quantification of the paint models}

The protein quantification is calculated in terms of the amount of protein recovered as a percentage of the theoretical value of the total protein present in a paint microsample which is also known as the yield of protein recovered. Therefore, the values obtained from the Bradford assay which are in $\mu \mathrm{g} / \mathrm{ml}$ have to be converted into a percentage.

In Sect. 2.3.3, we mentioned that for each $1 \mathrm{mg}$ of sample, $150 \mu \mathrm{L}$ of PBS was added to it. As each paint model microsample had a different weight, and with the addition of nanoparticles, the total weight increases, which increases the overall volume of PBS added to the microsamples. Therefore, the volume of PBS present in each sample was different and with each extraction in process, the overall volume of PBS added triples. The overall volume of PBS in $\mu \mathrm{L}$ is converted to $\mathrm{mL}$. This is an important step for our calculation. As the protein 
recovery values obtained in $\mu \mathrm{g} / \mathrm{mL}$ are multiplied to the volume of $\mathrm{PBS}$, which gives the protein recovery values in terms of $\mu \mathrm{g}$.

$$
\begin{aligned}
\text { Protein recovered }(\text { in } \mu \mathrm{g})= & \text { Protein recovered }\left(\frac{\mu \mathrm{g}}{\mathrm{mL}}\right) \\
& \times \text { Volume of } \operatorname{PBS}(\mathrm{mL})
\end{aligned}
$$

To find the percentage of the protein recovered from the paint models, it was important to compute the maximum amount (total) of protein that could be attained theoretically from $1 \mathrm{mg}$ of each sample.

For this calculation, it is important to understand the parameters needed to arrive at such an outcome. The first important information to know is how much protein does each milligram of a paint microsample have. Further, these paint models have samples without pigments, and other samples with pigments. The samples without pigments (samples 2, 7, 5, 8) have $100 \%$ binder present in their microsamples, i.e. in $1 \mathrm{mg}$ there is $1 \mathrm{mg}(1000 \mu \mathrm{g})$ of protein binder. The samples with pigments (samples 12, 22, 32, 42) have a pigment to binder ratio of $3: 1$, i.e. for $1 \mathrm{mg}$ of sample, there is $750 \mu \mathrm{g}$ of pigment, and $250 \mu \mathrm{g}$ of protein binder; which means the binder constitutes $25 \%$ of a $1 \mathrm{mg}$ microsample.

In protein binders, the actual protein content present would be a fraction of the binder. From the literature, it can be noted that proteins present in albumin, casein and collagen binders are estimated to constitute anywhere between 20-30\% of the total binder output. Therefore, to have consistent results, we have assumed the protein fraction to be at $25 \%$ of the total binder value.

Therefore, we can have two different formulas for the above two situations:

a. without pigment and $\mathrm{b}$. with pigment

$$
\begin{aligned}
\text { Theoretical total protein value (in } \mu \mathrm{g})= & \text { Sample weight (in } \mathrm{mg} \text { ) } \\
& \times 0.25 \times 1000
\end{aligned}
$$

Theoretical protein value (in $\mu \mathrm{g}$ ) $=$ Sample weight (in $\mathrm{mg}$ )

$$
\times 0.25 \times 0.25 \times 1000
$$

Once the theoretical values and protein recovery values are known in terms of $\mu \mathrm{g}$, the percentage of protein recovered can be calculated as follows:

$$
\begin{aligned}
\text { Percentage of protein recovered }= & (\text { Protein recovered }(\mu \mathrm{g}) \\
& \div \text { Theoretical protein }(\mu \mathrm{g})) \times 100
\end{aligned}
$$

Therefore, with the help of the above equations, it is possible to know how much protein was recovered by each extraction method (i.e. original protein extraction, with $\mathrm{NPSiO}_{2}$, MCM-41 uncalcined, MCM-41 calcined) separately for each of the paint models.

Finally, to understand the correctness of our research, the statistical analyses was computed with SPSS on ANOVA software by taking into consideration three different trials (SET A, $\mathrm{B}$ and C) that were performed separately with each extraction method.

\subsubsection{Indirect ELISA immunodetection of antigens (proteins)}

The paint binders have one or more proteins which serve as the antigen. When these antigens encounter an antibody of the same origin, it binds to the antibody and a biochemical reaction (assay) take place. The protocol followed for ELISA is as given from Salvador et al. given in [1]. Commercial solutions of ovalbumin, casein and collagen were used to compare the 


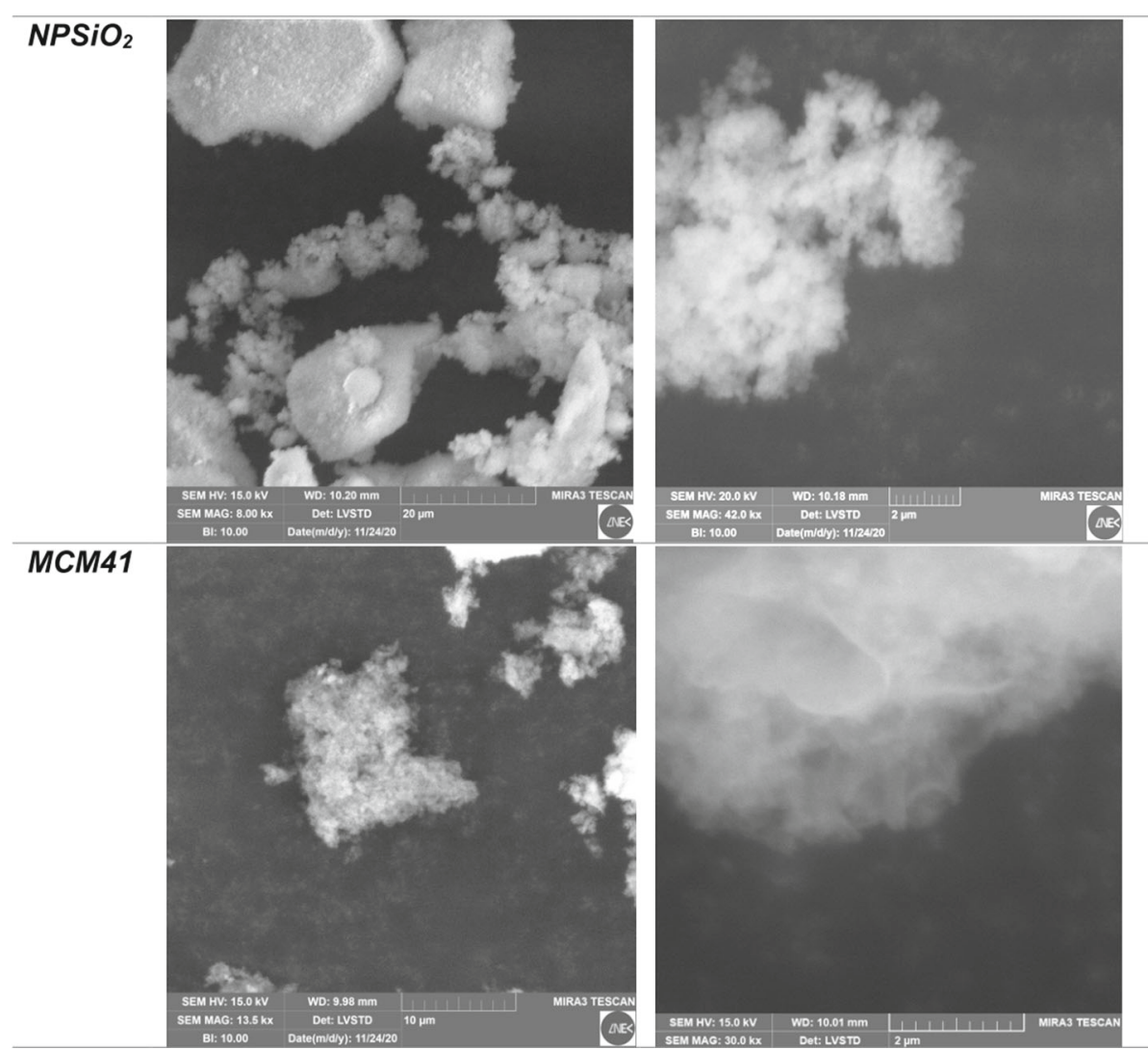

Fig. 2 SEM micrographs for $\mathrm{NPSiO}_{2} \& \mathrm{MCM} 41$

outcome of ELISA with paint model samples while using commercial primary and secondary antibodies. Ovalbumin and collagen ELISA tests were performed with monoclonal primary and secondary antibodies, whereas casein was done with polyclonal primary and secondary antibodies.

\section{Results and discussions}

\subsection{Nanoparticles characterization}

Figure 2 shows the SEM images of these materials at various resolutions. It is possible to compare between the real particle size as the magnification increases. For $\mathrm{NPSiO}_{2}$, the particles seem to be spherical in shape often producing aggregates, whereas for the MCM41 , large aggregates are formed but the particle morphology is undefined varying from small particles to larger foiled shapes. In both cases, the aggregates seem to have low adhesion between particles.

In Fig. 3, the XRD patterns of MCM-41 and $\mathrm{NPSiO}_{2}$ are shown. The diffraction pattern for both materials exhibit the typical pattern of amorphous silica with a broad peak from 


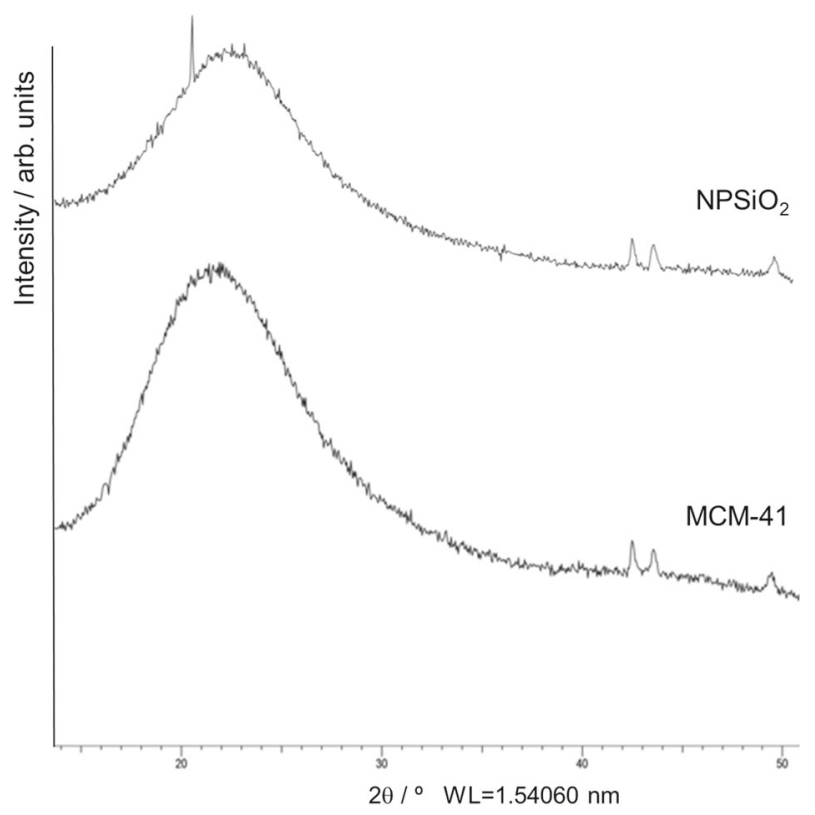

Fig. 3 XRD images of $\mathrm{NPSiO}_{2}$ and MCM41

Table 3 BET surface area of the silica-based nanoparticles

\begin{tabular}{llll}
\hline Property & $\mathrm{NPSiO}_{2}\left(\mathrm{~m}^{2} / \mathrm{g}\right)$ & $\mathrm{MCM}-41$ uncalcined $\left(\mathrm{m}^{2} / \mathrm{g}\right)$ & $\mathrm{MCM}-41$ calcined $\left(\mathrm{m}^{2} / \mathrm{g}\right)$ \\
\hline BET surface area & 6.96 & 201.85 & 788.52 \\
\hline
\end{tabular}

16 to $28^{\circ}$. Furthermore, $\mathrm{NPSiO}_{2}$ shows a sharp peak at $21^{\circ}$ typical of monodisperse silica nanoparticles. This indicates that even though they both are forms of silica nanoparticles, they are different from one another.

The nitrogen $\mathrm{N} 2$ porosimetry was done at $77 \mathrm{~K}$ in a vacuum after degasification at $255 \mathrm{~K}$ for $4 \mathrm{~h}$ with an equilibration interval of $10 \mathrm{~s}$ and sample density of $1.000 \mathrm{~g} / \mathrm{cm}^{3}$. The isotherm of $\mathrm{NPSiO}_{2}$ is type II typical of a non-porous samples and multilayer physical adsorption, while the isotherm for calcined MCM-41 is type IV typical of mesoporous samples presenting an hysteresis loop due to capillary condensation. The simplified surface area values given by the application of the BET equation (BET surface area) are given in Table 3.

From Table 3, it can be noted that the BET surface area is the highest in the calcined MCM-41 with $788,5232 \mathrm{~m}^{2} / \mathrm{g}$ and the lowest in $\mathrm{NPSiO}_{2}$ with $6,9630 \mathrm{~m}^{2} / \mathrm{g}$. The value of BET surface area for uncalcined MCM-41 might be overestimated due to degasification conditions that might have degraded part of the template surfactant. The isotherms and the BET surface area plot can be referred to in Appendix 1. As we will see further that the surface area and pore volume would be correlated to the protein recovery $\%$ from the paint models.

\subsection{Protein recovery and comparison of micro-extraction techniques}

As given in Sect. 3, there were different micro-extraction techniques utilized for the comparison of the protein recovered in each method. The purpose was to investigate whether the 
nanoparticles provide an added advantage for recovering proteins from paint microsamples more efficiently than the original extraction procedure. We started with the original procedure and then ventured into silica nanoparticles and MCM-41 in both uncalcined and calcined states. In Fig. 4, it is possible to see the difference in protein recovered in each extraction (first, second and third) from the paint models of ovalbumin $(2,7,12,22)$, collagen $(5,32)$, and casein $(8,42)$ with and without the presence of nanoparticles for each of the four techniques.

The percentage of protein recovery for each extraction was performed according to the formulas in Sect. 2.3.4. After calculating each extraction for each paint microsample, it was possible to portray how the micro-extraction kinetics vary for the three extractions and also compare the differences for each sample with the different techniques.

In Fig. $4 \mathrm{a}$, the $\%$ of protein recovered from the original extraction procedure shows a general trend of increase-decrease-increase during the first-second-third extractions in all paint models. The protein recovery of sample 2 is the highest among other extraction techniques. In all the paint models, the first extraction has the highest $\%$ protein recovery with respect to the other extractions. Sample 7 has the highest percentage for the first, second and third extraction, and sample 22 has the least among all paint models.

Sample 12 which is an ovalbumin-based paint model has a high recovery percentage even though it contains a pigment. Samples 32 and 42 contain pigments and have a better recovery than their protein binders (collagen \& casein) without any pigments (samples 5 and 8).

In Fig. 4b, the protein recovery with $\mathrm{NPSiO}_{2}$ shows a general trend of increase-decrease-increase during the first-second-third extractions in all paint models. Sample 2 has a similar pattern to the original procedure, but with a little bit lower content of protein in the three extractions. Sample 7 also follows the similar pattern of the original technique but with bit lower values. The first extraction of sample 12 is the highest protein recovery among all other paint models, while it reaches an even higher percentage of recovery than the original extraction at about $24 \%$. The third extraction of the sample 12 is also higher than the original extraction technique. Samples 5, 32, 8, 42 all have a slight increase in the protein recovery than the original technique. The second extraction of sample 5 has the lowest protein recovery in this technique.

In Fig. 4c, the protein recovery is shown with MCM-41 before calcination and shows more or less the same general trend of increase-decrease-increase during the first-second-third extractions in all paint models. Samples 2 and 7 have very low protein recovery in all extractions in comparison with the first two methods. Sample 12 also has a lower protein recovery than the previous two extraction techniques, but not as low in respect to samples 2 and 7 . Sample 22 here has a higher protein recovery than the original technique, but lower protein recovery than with $\mathrm{NPSiO}_{2}$. Samples 5 and 32, which are proteins of collagen, have the highest protein recovery in comparison with the other two techniques, and this increase is quite drastic. Samples 8 and 42, which are proteins of casein, have the lowest protein recovery in comparison with the previous two methods.

In Fig. 4d, the protein recovery is shown with MCM-41 after calcination and does not follow any particular trend among the paint models for the three extractions. Sample 2 has a low protein extraction, similar to the MCM-41 before calcination. Sample 7 has a higher protein recovery than MCM-41 before calcination, but still the protein values are very low indeed. Sample 12 in the first extraction has the highest protein values among all other techniques for this paint model. It recovers above $30 \%$ of the protein, although the other two extractions do not result in much output. Sample 22 has a low first extraction, but the second and third extractions are the highest among the other extraction techniques. This leads it to be the highest protein recovery technique for this paint model. Sample 5 has a low protein recovery than $\mathrm{NPSiO}_{2}$ and MCM-41 uncalcined, but almost equivalent to the original 
(a) Original protein extraction procedure

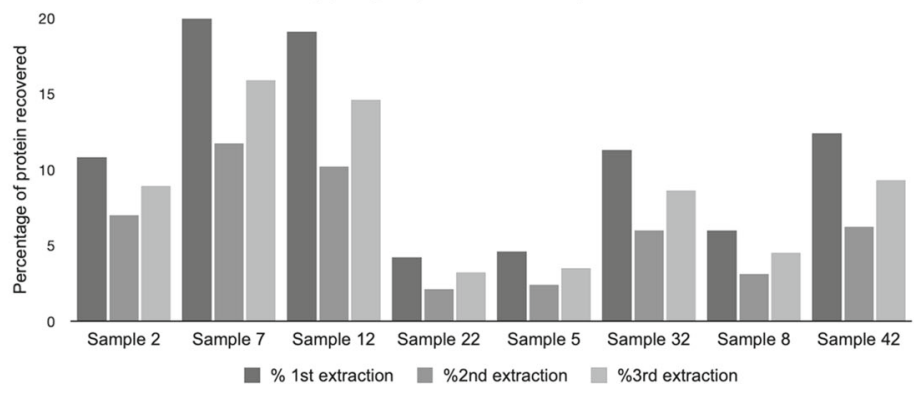

(b) Protein extraction with $\mathrm{NPSiO} 2$

30

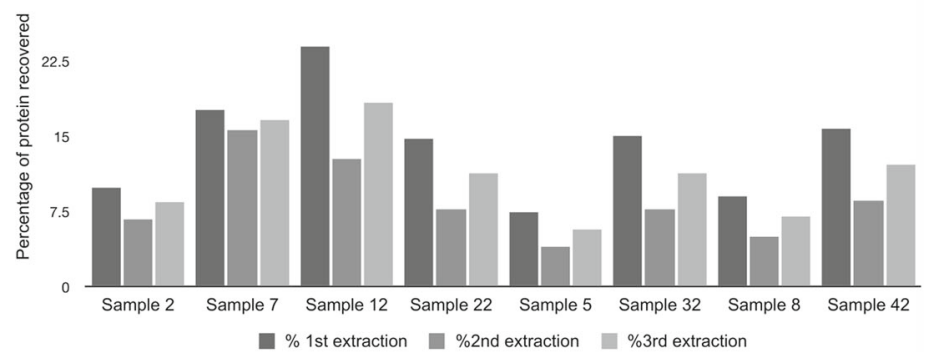

(c) Protein extraction with MCM41 before calcination

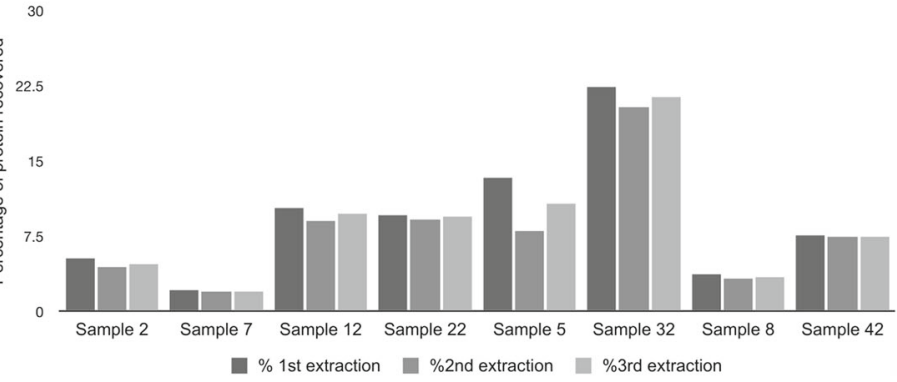

(d) Protein extraction with MCM41 after calcination

40

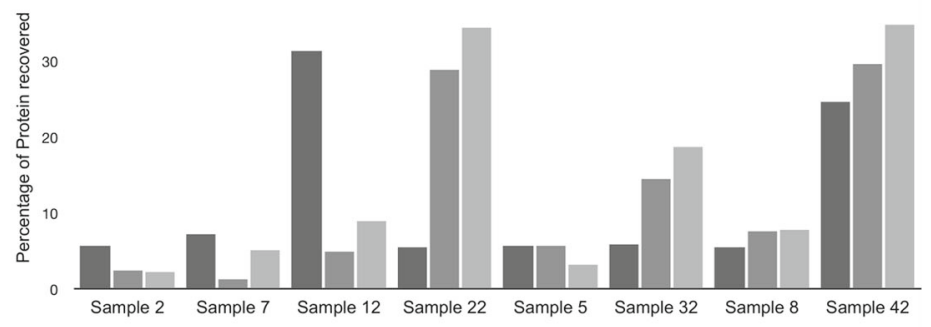

—1st extraction — \%2nd extraction $\quad \% 3 r d$ extraction

Fig. 4 Percentage of protein recovery for each extraction from paint microsamples $\mathbf{a}$ original extraction $\mathbf{b}$ with $\mathrm{NPSiO}_{2} \mathbf{c}$ with uncalcined MCM-41 d with calcined MCM-41 


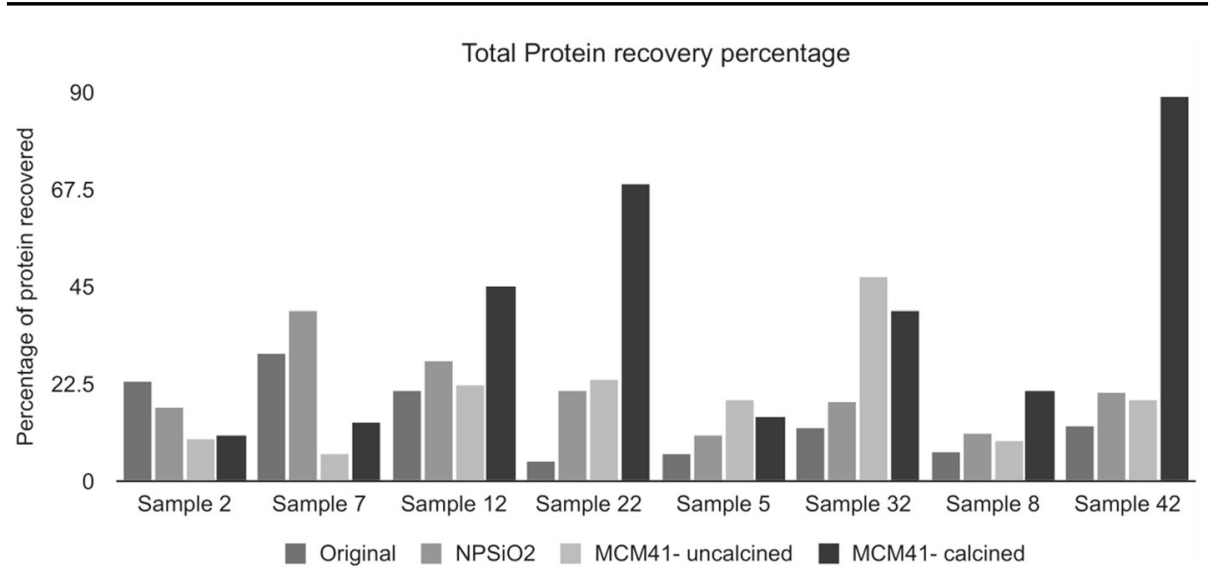

Fig. 5 Total \% of protein recovery from the paint model samples

procedure. Sample 32 has a step wise increase in protein recovery with each extraction. The third extraction almost retains $20 \%$ of the protein. Sample 8 has a low first extraction and an equivalent second and third extraction. Sample 42 has the highest protein recovery percentage among all paint models and other techniques while following a stepwise recovery trend.

Furthermore, the above results were combined to find the overall protein recovery. Figure 5 shows the total percentage of protein that was recovered from the paint models with each technique.

Except for the case of sample 2, all the other paint models had a larger amount of protein recovered with the use of the nanoparticles. In sample 7, the extraction with $\mathrm{NPSiO}_{2}$ has the highest yield. In samples 12 and 22, which contain an ovalbumin binder and lead white pigment showed maximum protein recovery with the calcined MCM-41. For samples 5 and 32, which have a collagen binder, the uncalcined MCM-41 recovers the most protein, while the calcined MCM-41 follows next with just being a little bit lower. Samples 8 and 42, which have a casein binder, had maximum recovery with the calcined MCM-41. All the samples with the pigment lead white $(12,22,32,42)$ have a drastic increase in the overall protein recovered with MCM-41 in comparison with the original procedure or $\mathrm{NPSiO}_{2}$. In real paintings, the paint microsamples always contain pigments [1]; therefore, this analysis holds importance for immunodetection with nanoparticles for real paint binders from real paintings.

In the samples with ovalbumin as the binder, the samples with pigments, i.e. samples 12 and 22, recover more protein with MCM-41, whereas the samples without pigments, i.e. samples 2 and 7, prefer the original extraction procedure. Since ovalbumin is a globular protein, it is strongly affected by the $\mathrm{pH}$ of the system. In our case, the phosphate buffer PBS has a $\mathrm{pH}=7,4$ which makes sure that ovalbumin is extracted from the paint samples but when the system contains silica nanoparticles, the globular proteins being small in size would easily adsorb and load on the surface of the silica nanoparticles while also changing the $\mathrm{pH}$ of the system. This intervention of silica nanoparticles traps ovalbumin making it very hard for them to escape into solution.

In case of the pigments being present, the pigment-to-binder ratio is high (3:1); therefore, the pigments are strongly bounded to the binder. This makes it harder to recover proteins with the original extraction procedure. When the silica nanoparticles are present in the system, the proteins do still get partially adsorbed on the surface while still being unable to detach from 
the pigment. This forms a nanoparticle-protein-pigment complex, with both the nanoparticle and pigment competing to attract more protein within their vicinity. Eventually, the opposing forces cancel out each other to allow the protein to escape into the solution. This theory would hold true for the other paint models with pigments and collagen or casein binder, i.e. samples 32 and 42 where the protein recovery is almost 4 times that over their counterparts without pigments, i.e. samples 5 and 8.

In the collagen paint models samples 5 and 32, the protein recovered in the uncalcined MCM-41 is slightly higher than the calcined MCM-41. This is largely due to the large size of collagen and the presence of the surfactant CTAB. The collagen proteins which after initially being attracted to adsorb on the surface of MCM-41 encounter CTAB which rapidly pushes the proteins right out into the solution, whereas after calcination, CTAB is eliminated which allows the collagen proteins to be more tightly adhered on the surface of the MCM-41 than before calcination. Although due to its large size, eventually, it does fall out into solution, making it possible to fine-tune the protein released.

Casein paint models, i.e. samples 8 and 42, highly prefer the calcined MCM-41 extraction. This is because the uncalcined MCM- 41 has the surfactant CTAB, and casein prefers to attach to it as they both are hydrophobic in nature. This causes the MCM-41 in its uncalcined state to finally get rid of surfactant loving casein with eventually causing a very large spike in protein recovery.

The increase in $\mathrm{NPSiO}_{2}$ and MCM-41 is due to their high protein loading capacity, large pore size and easy encapsulation of the proteins on its surface which can then be fine-tuned for nanoparticle-based protein release and delivery [32-35]. This research shows how nanoparticles could help in the total protein extraction and quantification of paint microsamples by boosting the proteins through protein-nanoparticle surface interaction.

Finally, the protein recovery statistical analysis shows significant $(p<0.05)$ increase in protein recovery, above 1.3 times for $\mathrm{NPSiO}_{2}$ and above 1.6 times for MCM-41. The statistical data supports the results obtained from the protein quantification and recovery.

\subsection{Effect of silica nanoparticles on Immunoassays of paint models}

The ultimate goal of the silica nanoparticles is to see whether they affect the detection of proteins during immunodetection. The nanoparticles boost the protein recovery from the individual samples, and therefore it is important to understand the efficacy for immunoassays such as immunodetection in combination with protein extracts from silica nanoparticles.

Table 4 demonstrates the change in activity in terms of $\mathrm{Uml}^{-1}$ for ELISA immunodetection with and without nanoparticles. As the calcined MCM-41 protein recovery demonstrated immense potential among the silica nanoparticles (i.e. $\mathrm{NPSiO}_{2}$, uncalcined MCM-41, calcined MCM-41) used for this investigation, we decided to assess the calcined MCM-41 as the right choice for comparison with the proteins from the paint models. From this table, there is clear correlation between the increase in detection activity and the increase in protein recovery obtained with calcined MCM-41.

Therefore, in conclusion, a general trend of increase in protein concentration with the addition of silica particles was observed. The results of this research are a new dimension added to the investigation of protein binders from artworks. The above study shows that it is possible for silica nanoparticles to increase protein detection and extraction from paint binders, although further study of different pigments and different types on nanoparticles is required to understand the protein-nanoparticle dynamics and the effects on current immunodetection methodologies. The future works for expanding this study would be to produce 
Table 4 Immunodetection activity with and without nanoparticles

\begin{tabular}{lrc}
\hline Sample & Without nanoparticles $\left(\mathrm{Uml}^{-1}\right)$ & With calcined MCM41 $\left(\mathrm{Uml}^{-1}\right)$ \\
\hline 2-Egg white & $10.65 \pm 2.158$ & $14.51 \pm 0.342$ \\
7-Whole Egg & $8.1 \pm 0.723$ & $8.178 \pm 0.168$ \\
12-Egg white + lead white & $0.86 \pm 3.496$ & $2.098 \pm 0.231$ \\
22-Whole Egg + lead white & $11.38 \pm 1.865$ & $16.865 \pm 0.177$ \\
Commercial ovalbumin & $19.32 \pm 2.399$ & $31.399 \pm 0.894$ \\
5-Rabbit skin & $7.9 \pm 0.156$ & $17.206 \pm 0.334$ \\
32-Rabbit glue + lead white & $0.7 \pm 0.139$ & $3.826 \pm 0.203$ \\
Commercial collagen & $1.785 \pm 0.361$ & $3.563 \pm 0.943$ \\
8-casein cow's milk & $1.69 \pm 0.469$ & $6.446 \pm 0.265$ \\
42-casein cow's milk + lead white & $0.89 \pm 0.222$ & $6.214 \pm 0.074$ \\
Commercial casein & $2.01 \pm 0.252$ & $9.33 \pm 0.547$ \\
\hline
\end{tabular}

paint models using a mixture of more pigments, protein binders, varnishes that simulate complex matrices which represent real paintings.

Acknowledgements The authors acknowledge for financial support to ED-ARCHMAT grant agreement number 766311 (Project ESR2) Marie Sklodowska-Curie Innovative Training Networks, Horizon 2020 and THE SCREAM Project-Touchstone for Heritage Endangered by Salt Crystallization, a Research Enterprise on the Art of Munch, Ref: ALT20-03-0145-FEDER-031577 and the City University of Macao endowment for the Sustainable Heritage Chair.

Author contributions ASG involved in manuscript writing, data interpretation, concept and experimental analysis; CS involved in supplying the paint models; AC involved in nanoparticle characterization and data interpretation; ATC involved in concept and supervision; CM involved in supervision.

Data availability Data available on request from the authors.

\section{Declarations}

Conflict of interest Cátia Salvador, António Candeias, Carole Mathe and Ana Teresa Caldeira certify that they do not have any affiliations leading to a conflict of interest about the subject matter discussed in this project. Aditya Sandeep Goyal certifies that he does not have any affiliations that would give rise to any conflict regarding any and all of the materials and subject matter discussed in this article.

Open Access This article is licensed under a Creative Commons Attribution 4.0 International License, which permits use, sharing, adaptation, distribution and reproduction in any medium or format, as long as you give appropriate credit to the original author(s) and the source, provide a link to the Creative Commons licence, and indicate if changes were made. The images or other third party material in this article are included in the article's Creative Commons licence, unless indicated otherwise in a credit line to the material. If material is not included in the article's Creative Commons licence and your intended use is not permitted by statutory regulation or exceeds the permitted use, you will need to obtain permission directly from the copyright holder. To view a copy of this licence, visit http://creativecommons.org/licenses/by/4.0/. 
(a) + Isotherm Linear Plot

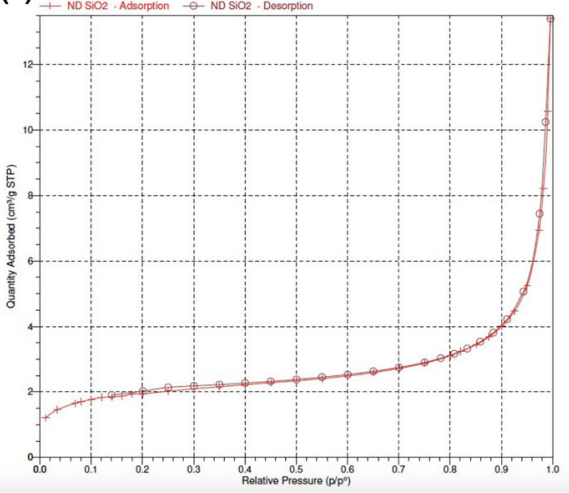

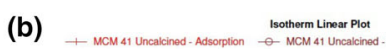

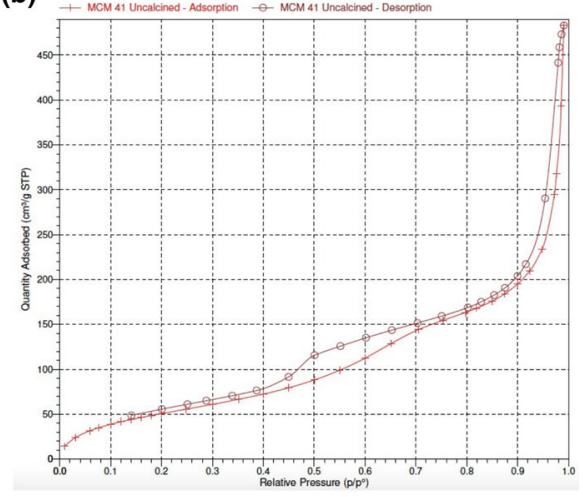

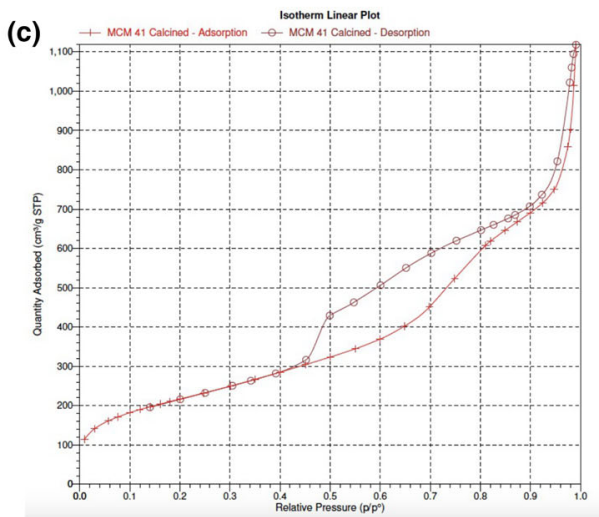

Fig. 6 Isotherms of nitrogen porosimetry of $\mathbf{a} \mathrm{NPSiO}_{2}$ b $\mathrm{MCM}-41$ uncalcined $\mathbf{c} \mathrm{MCM}-41$ calcined

\section{Appendix 1}

See Fig. 6. 


\section{References}

1. C. Salvador, A. Branco, A. Candeias, A.T. Caldeira, Innovative approaches for immunodetection of proteic binders in art. e-conserv. J. 5, 1-1 (2017). https://doi.org/10.18236/econs5.201708

2. M.G. Giuffrida, R. Mazzoli, E. Pessione, Appl. Microbiol. Biotechnol. 102(13), 5445-5455 (2018)

3. E. Barberis, S. Baiocco, E. Conte, F. Gosetti, A. Rava, G. Zilberstein, P.G. Righetti, E. Marengo, M. Manfredi, Microchem. J. 139, 450-457 (2018)

4. C. Salvador, M. Silva, T. Rosado, R.V. Freire, R. Bordalo, A. Candeias, A.T. Caldeira, Conserv. Patrim. 23, 119-124 (2016)

5. L. Cartechini, M. Vagnini, M. Palmieri, L. Pitzurra, T. Mello, J. Mazurek, G. Chiari, Acc. Chem. Res. 43, 867-876 (2010)

6. M. Palmieri, M. Vagnini, L. Pitzurra, L. Cartechini, Anal Bionanal Chem. 405, 6365-6371 (2013)

7. L. Cartechini, M. Palmieri, M. Vagnini, L. Pitzurra, Top Curr. Chem (Z) 374, 5 (2016)

8. Y. Liu, Y. Li, R. Chang, H. Zheng, M. Li, Z. Hu, Y. Zhou, B. Wang, Anal. Sci. 32, 735-740 (2016)

9. W. Hu, H. Zhang, B. Zhang, Microsc. Microanal. 21(5), 1278-1287 (2015)

10. S. Wu, C. Mou, H. Lin, Chem. Soc. Rev. 42, 3862-3875 (2013)

11. Z. Chen, C. Wu, Y. Yang, J. Shi, J. Hu, Z. Yang, Z. Chen, Eur. J. BioMed. Res. 1, 30-36 (2015)

12. P. Baglioni, E. Carretti, D. Chelazzi, Nat. Nanotechnol. 10, 287-290 (2015)

13. W.I. Hahens, A.G. Oomen, W.H. deJong, F.R. Cassee, Regul. Toxicol. Pharmacol. 49, 217-229 (2007)

14. N. Rajput, Int. J. Adv. Res. Technol. 7(4), 1806-1811 (2015)

15. S.L. Pal, U. Jana, P.K. Manna, G.P. Mohanta, R. Manavalan, J. Appl. Pharm. Sci. 01(06), 228-234 (2011)

16. S. Wang, Microporous Mesoporous Mater. 117, 1-9 (2009)

17. C.X. Lin, S.Z. Qiao, C.Z. Yu, S. Ismadji, G.Q. Lu, Microporous Mesoporous Mater. 117, 213-219 (2009)

18. I. Izquierdo-Barba, A. Martinez, A.L. Doadrio, J. Perez-Pariente, M. Vallet-Regi, Eur. J. Pharm. Sci. 26, 365-373 (2005)

19. G. Maria, D. Berger, S. Nastase, I. Luta, Microporous Mesoporous Mater. 149, 25-35 (2012)

20. A. Zeid, A.L. Othman, Materials 5, 2874-2902 (2012)

21. S.W. Song, K. Hidajat, S. Kawi, Langmuir 21, 9568-9575 (2005)

22. P. Horcajada, A. Ramila, J. Perez-Pariente, M. Vallet-Regi, Microporous Mesoporous Mater. 68, 105-109 (2004)

23. G. Maria, A. Stoica, I. Luta, D. Stirbet, G.L. Radu, Microporous Mesoporous Mater. 162, 80-90 (2012)

24. C.T. Kresge, M.E. Leonowicz, W.J. Roth, J.C. Vartuli, J.S. Beck, Nature 359, 710-712 (1992)

25. A. Monnier, F. Schüth, Q. Huo, D. Kumar, D. Margolese, R.S. Maxwell, G.D. Stucky, M. Krishnamurty, P. Petroff, A. Firoouzi, M. Janicke, B.F. Chmelka, Science 261, 1299-2130 (1993)

26. M.A. Karakassides, A. Bourlinos, D. Petridis, L. Coche-Guerente, P. Labbe, J. Mater. Chem. 10, 403-408 (2000)

27. F. Hoffmann, M. Cornelius, J. Morell, M. Froba, Angew. Chem. Int. Ed. 45, 3216-3251 (2006)

28. N. Cao, Y. Zhao, B. Sang, Z. Wang, L. Cao, L. Sun, X. Zou, Mater. Sci. Eng. C 69, 330-336 (2016)

29. W. Stober, A. Fink, E. Bohn, J. Colloid Interface Sci. 26, 62-69 (1968)

30. T. Kiyoharu, K. Morita, K. Mori, M. Tatsumisago, J. Sol-Gel Sci. Technol. 68(2), 341-345 (2011)

31. V. Ravat, D. Mantri, P. Selvam, P. Aghalayam, J. Mol Catal A Chem. 314, 49-54 (2009)

32. J. Tu, A.L. Boyle, H. Friedrich, P.H.H. Bomans, J. Bussmann, N.A.J.M. Sommerdijk, W. Jiskoot, A. Kros, A.C.S. Appl, Mater. Interfaces 8(47), 32211-32219 (2016). https://doi.org/10.1021/acsami.6b11324

33. B. Bharti, J. Meissner, S.H.L. Klapp, G.H. Findenegg, Soft Matter 10, 718-728 (2014)

34. M. Lundqvist, I. Sethson, B. Jonsson, Langmuir 20(24), 10639-10647 (2004). https://doi.org/10.1021/ $1 \mathrm{a} 0484725$

35. C. Xu, C. Lei, C. Yu, Front. Chem. 7, 290 (2019) 